\title{
GROWTH AND MORTALITY OF BLACK BASS, Micropterus salmoides (PISCES, CENTRACHIDAE; LACAPÈDE, 1802) IN A RESERVOIR IN SOUTHERN BRAZIL
}

\author{
SCHULZ, U. H. and LEAL, M. E. \\ Universidade do Vale do Rio dos Sinos, UNISINOS, Centro de Ciências da Saúde, \\ Laboratório de Ecologia de Peixes, C.P. 275, CEP 93022-000, São Leopoldo, RS, Brazil \\ Correspondence to: Uwe H. Schulz, Universidade do Vale do Rio dos Sinos, UNISINOS, Centro de \\ Ciências da Saúde, Laboratório de Ecologia de Peixes, C.P. 275, CEP 93022-000, São Leopoldo, RS, \\ Brazil, e-mail: uwe@bios.unisinos.br \\ Received August 19, 2003 - Accepted October 23, 2003 - Distributed May 31, 2005
}

(With 3 figures)

\begin{abstract}
The black bass, Micropterus salmoides, was introduced to Brazil from North America in 1922. Since then the species has been reared in aquaculture facilities intended to stock reservoirs as additions to native stocks available for angling. At present no scientific information on the biology of black bass in Brazilian waters is available. Since black bass dispersion may cause severe impacts on native Brazilian fish fauna, information on the basic biological parameters of this species is necessary. The objective of the present study is to provide information on the growth, age structure, and mortality of the species in a small reservoir in southern Brazil, where the species reproduces regularly. Based on scale readings, the von Bertalanffy growth curve was calculated and compared to the lengthfrequency distribution of the population. Both methods showed similar results. Maximum length was about $44 \mathrm{~cm}$. The mean length at the end of the first year was $23.1 \mathrm{~cm}$ (s.d. = 13.88); at that of the second, $37.3 \mathrm{~cm}($ s.d. = 12.52); and $41.4 \mathrm{~cm}($ s.d. = 9.92) at the third. Oldest fish were three years old. The growth performance index $\emptyset^{\prime}$ was $3.28 \mathrm{~cm}$ year $^{-1}$. Mortality increased from 0.16 year $^{-1}$ between the first and the second cohort, to 0.8 year $^{-1}$ between the second and third. The results show that black bass in Brazil grows faster than in its area of origin, but longevity is shorter and body shape, stouter. The cause of high mortality at a relatively early age may be connected with the loss of genetic diversity due to inbreeding of the Brazilian stocks, which originated from few introduced individuals a long time ago. The fact that black bass reproduces in reservoirs and grows rapidly may be considered a threat to conserving fish diversity in Brazilian ecosystems.
\end{abstract}

Key words: Micropterus salmoides, growth, mortality.

\section{RESUMO}

Crescimento e mortalidade do black bass, Micropterus salmoides, (Pisces, Centrachidae; Lacepède, 1802) num reservatório no sul do Brasil

O black bass, Micropterus salmoides, proveniente da América do Norte, foi introduzido no Brasil em 1922. A partir dessa data, a espécie foi criada na piscicultura brasileira para fins de soltura em açudes e reservatórios com o objetivo de sustentar a pesca amadora. Atualmente não há informações sobre a biologia da espécie em águas brasileiras. Como a dispersão da espécie em águas naturais pode causar impactos imprevisíveis, é necessário levantar dados sobre parâmetros básicos de sua biologia. O objetivo do presente trabalho é investigar o crescimento, a estrutura etária e a mortalidade da espécie num pequeno reservatório no sul do Brasil, onde ela se reproduz todos os anos. Por meio da leitura de escamas foi calculada a curva de crescimento von Bertalanffy e comparada à distribuição do comprimento. Ambos os métodos chegaram a resultados similares. O comprimento máximo foi de aproximadamente $44 \mathrm{~cm}$. No primeiro ano de vida, o comprimento médio foi de $26,1 \mathrm{~cm}(\mathrm{~d} . \mathrm{p}$. = 13,88); no segundo, 37,3 cm (d.p. = 12,52); e no terceiro, 41,5 cm (d.p. =9,92). O índice de per- 
formance de crescimento foi $\emptyset^{\prime}=3,28 \mathrm{~cm}^{2} \mathrm{ano}^{-1}$. A mortalidade $\mathrm{Z}$ aumentou aproximadamente quatro vezes, de 0,16 anos $^{-1}$ entre a primeira e a segunda coorte para 0,8 anos ${ }^{-1}$ entre a segunda e a terceira coorte. Os resultados mostram que o black bass cresce mais rapidamente no Brasil e tende a ser mais enxuto que em sua área de origem, mas não atinge a longevidade dos espécimes nos Estados Unidos. A causa dessa mortalidade elevada é vista na provável diminuição da diversidade genética dos estoques brasileiros, originados de poucos indivíduos introduzidos muito tempo atrás. O fato de a espécie se reproduzir e crescer rapidamente em sistemas seminaturais pode ser considerado uma ameaça para a conservação dos ecossistemas brasileiros.

Palavras-chave: Micropterus salmoides, crescimento, mortalidade.

\section{INTRODUCTION}

The introduction of exotic species has major impacts on native fauna. On an international scale, such introductions contribute to the globalization of fauna, while on a regional scale they can lead to homogenization (Scott \& Helfman, 2001; Zanatell \& Rassam, 2002). Introduced species can cause complex changes in structure and function in the new ecosystem. Such impacts include a change of existing food webs, habitats, importation of new diseases and parasites, and competition with native species for food resources and space (Moyle \& Cech Jr., 2000). Based on these facts, the Invasive Species Specialist Group compiled a "100 worst invasive species of the world" list, which includes the black bass (Micropterus salmoides) in the fish section (ISSG, 1999).

The black bass or largemouth bass is a North American species of the centrachid family. Its native distribution includes the area between the Hudson Bay basin and the St. Lawrence-Great Lakes basin to the Mississippi River basins, and the Atlantic drainages from North Carolina to Florida and northern Mexico (Page \& Burr, 1991). It is commonly found in slow flowing, warm, and turbid rivers or lakes (Tomelleri \& Eberle, 1990). Black bass is one of the favorite game fish of anglers who in the USA constitute an economically important sector responsible in 1996 for spending 38 billion dollars on equipment, travel, and other fishingrelated expenses (United States Department of the Interior et al., 1996). The black bass is a major predator, feeding on zooplankton, insects, and other invertebrates as juveniles, and preying on crustaceans, fish, and other small vertebrates as adults (Aloo \& Dadzie, 1995; García-Berthou, 2002; Hickley et al., 1994). Maximum recorded length is $97 \mathrm{~cm}$ (Page \& Burr, 1991) and maximum weight is $10.09 \mathrm{~kg}$ (Tomelleri \& Eberle, 1990).

The species was introduced for sport-fishing purposes in many countries like Japan (Yodo \& Kimura, 1996), Kenya (Aloo \& Dadzie, 1995), Mozambique (Weyl \& Hecht, 1999), Italy (Lorenzoni et al., 2002), Spain (Elvia \& Almodóvar, 2001), and Portugal (Colares-Pereira et al., 1999). In almost all of such countries, undesirable side effects on native fauna have been reported. Micropterus salmoides introduction to Brazil was documented by Godoy (1954). The species was introduced in 1922 by Jair Lins of Belo Horizonte. After several frustrated attempts he finally succeeded in his efforts to reproduce the species in captivity. Today the black bass is widely distributed in artificial systems like angling ponds, and semi-natural systems like reservoirs, from Rio de Janeiro to Rio Grande do Sul. In these systems black bass frequently form self-reproducing populations. No published scientific information about the dispersion of this species in Brazilian rivers and lakes is currently available, nor are publications on growth or other basic population parameters, which are essential for impact assessment of black bass on native fish communities.

The objective of this study was to analyze growth, age structure, and mortality of a black bass population in a small reservoir in São Leopoldo, RS, where the species was introduced in 1990 and reproduces regularly.

\section{MATERIAL AND METHODS}

Black bass were captured on two occasions in September 1999 and 2001 in a 2.7 ha reservoir on the campus of Universidade do Vale do Rio dos Sinos in São Leopoldo, southern Brazil (S2947.75', 
$\left.\mathrm{W} 51^{\circ} 09.47^{\prime}\right)$. The reservoir is located in the Rio dos Sinos watershed, Rio Grande do Sul.

In the first event, black bass were captured by electric fishing $(700 \mathrm{~V}$, max. $7 \mathrm{KW}$, direct current), using the hull of an aluminum boat as the cathode. On the second occasion, fish were captured with hook and line during an angling tournament.

All specimens were measured (total length and weight). From each individual, five to eight scales were collected from the body area between the lateral line and the dorsal fin (Devries \& Frie, 1996). Scales were cleaned under running water and immersed in hydrogen peroxide $(30 \%)$ to remove mucus and clear the structures. Damaged scales or scales with dubious annuli were discarded.

Growth was analyzed by scale reading and length frequency distribution. Scale reading followed Devries \& Frie (1996) and used the radius of the annuli, total radius of the scale, and total length for back-calculation of fish length at different ages. The von Bertalanffy growth curve was calculated on the basis of back-calculated lengths applying the equation

$$
\mathrm{L}_{\mathrm{t}}=\mathrm{L} \infty\left(1-\mathrm{e}^{-\mathrm{K}(\mathrm{t}-\mathrm{to})}\right)
$$

where $\mathrm{L}_{\mathrm{t}}$ predicts the length at age $\mathrm{t}$ (dimension: $\mathrm{cm}$ ); L $\infty$ is the theoretical total maximum length, which may be attained at infinite high age (dimension: $\mathrm{cm}$ ) (the growth curve approaches this value asymptotically); $\mathrm{K}$ varies between 0 and 1 and determines the approximation of the growth curve to $\mathrm{L}_{\infty}$ (dimension: year ${ }^{-1}$ ) (the higher the value of $\mathrm{K}$, the faster the approximation); $\mathrm{t}_{\mathrm{o}}=$ theoretical age at length zero (dimension: years); and $t_{0}$ is usually negative and considers that growth has already occurred between fecundation and hatching (Piscistat, 1991).

Since K cannot be used directly as the growth indicator because of its dimension year ${ }^{-1}$, the index of growth performance $\left(\varnothing^{\prime}=\log _{10} \mathrm{~K}+2 \log _{10} \mathrm{~L} \infty\right.$; dimension: $\mathrm{cm}$ year ${ }^{-1}$ ) was also calculated to compare growth of the studied population with that of others (Froese \& Pauly, 2000).

The length frequency distribution was used to identify cohorts. Mortality between cohorts was calculated by $\mathrm{N}_{0}=\mathrm{N}_{1} * \mathrm{e}^{(-\mathrm{Z} * \Delta t)}$, where $\mathrm{N}_{0}$ and $\mathrm{N}_{1}$ are the abundances of individuals in subsequent cohorts, $\mathrm{Z}$ is the total mortality rate, and $\Delta \mathrm{t}$ the time between the cohorts (= 1 year) (Froese \& Pauly, 2000). Since $Z$ is the sum of natural mortality and fishing mortality, fishing mortality was set to zero because no fishing was allowed in the reservoir, except for our experimental purpose.

The relation between fish weight and length is given by the equation $\mathrm{W}=\mathrm{a}^{*} \mathrm{~L}^{\mathrm{b}}$, where $\mathrm{W}$ is the weight and $\mathrm{L}$ is the length. The parameters a and b were calculated by linear regression between log $\mathrm{W}$ and $\log \mathrm{L}(\log \mathrm{W}=\mathrm{a}+\mathrm{b} \log \mathrm{L})($ SPSS, 1999). Regression parameter $b$ is a measure of stoutness, which means the tendency to attain higher weight at lower length. The regression parameters were compared to those of 60 populations in the U.S. and other countries, which were published in the Fishbase 2000 database (Froese \& Pauly, 2000).

\section{RESULTS}

A total of 134 black bass was collected with a total length ranging between $21 \mathrm{~cm}$ and $46.6 \mathrm{~cm}$, and weight of between $104.6 \mathrm{~g}$ and $1467.9 \mathrm{~g}$. Readable scales could only be found on 64 fish. The equation of the von Bertalanffy growth curve was calculated to be $\mathrm{L}_{\mathrm{t}}=43.91\left(1-\mathrm{e}^{-0.99(\mathrm{t}-0.09)}\right)$. Figure 1 displays the growth curve and shows the asymptotical approximation to $\mathrm{L}_{\infty}=43.91 \mathrm{~cm}$.

Length frequency distribution was trimodal, with each mode representing the mean length of a cohort (Fig. 2). The mean length of each cohort based on the von Bertalanffy method and on length frequency distribution is shown in Table 1. The comparison of growth parameters L $\infty, \mathrm{K}$, and $\varnothing^{\prime}$ of the studied population with those of others indicates fast growth in Brazil but a lower maximum length compared to that of populations in the U.S.A. and other countries (Table 2).

Since length frequency distribution identified three nonoverlapping cohorts (Fig. 2), the mortality between them could be calculated. Between the first and the second year, mortality was $Z=0.16$ year $^{-1}$ and between the second and the third year mortality increased fourfold to $\mathrm{Z}=0.8$ year $^{-1}$.

The relation between weight and length is given by the equation $\log \mathrm{W}=-2.32+3.28 \mathrm{~L}$. In Fig. 3 regression weight-length parameters a and b are plotted with regression parameters of 60 populations worldwide. The position of the Brazilian population above the regression line at the right half of the graph indicates that individuals of the studied population have a stouter body shape than most of the other populations worldwide. 
TABLE 1

Mean total length per year calculated by von-Bertalanffy-method and by length frequency distribution (modes); Std = standard deviation.

\begin{tabular}{|c|c|c|c|c|}
\hline $\begin{array}{c}\text { Age } \\
\text { (years) }\end{array}$ & $\mathbf{N}$ & $\begin{array}{c}\text { Total length } \\
(\mathbf{c m})\end{array}$ & Std & $\begin{array}{c}\text { Modes } \\
(\mathbf{c m})\end{array}$ \\
\hline 1 & 64 & 26.1 & 13.88 & 27 \\
\hline 2 & 18 & 37.31 & 12.52 & 37 \\
\hline 3 & 2 & 41.46 & 9.92 & 42 \\
\hline
\end{tabular}

TABLE 2

Comparison of von Bertalanffy growth parameters and growth index ø' of the Brazilian population and others; TL = Total length, SL = Standard length.

\begin{tabular}{|c|c|c|c|c|c|}
\hline State/Country & $\begin{array}{c}\text { Length } \\
\text { measure }\end{array}$ & $\begin{array}{c}\mathbf{L}_{\infty} \\
(\mathbf{c m})\end{array}$ & $\begin{array}{c}\mathbf{K} \\
\left(\mathbf{y e a r}^{\mathbf{- 1}}\right)\end{array}$ & $\begin{array}{c}\boldsymbol{\emptyset}^{\prime} \\
\left(\mathbf{c m}_{\mathbf{y}} \mathbf{- 1}\right)\end{array}$ & Author \\
\hline RS/Brazil & TL & 43.91 & 0.99 & 3.28 & Present study \\
\hline New York/USA & TL & 52.90 & 0.22 & 2.79 & Froese \& Pauly (2000) \\
\hline Minnesota/USA & TL & 58.90 & 0.16 & 2.74 & Froese \& Pauly (2000) \\
\hline Alabama/USA & TL & 62.50 & 0.28 & 3.04 & Froese \& Pauly (2000) \\
\hline Italy & TL & 51 & 0.28 & 2.87 & Froese \& Pauly (2000) \\
\hline Japan & SL & 34.1 & 0.5 & 2.76 & Froese \& Pauly (2000) \\
\hline
\end{tabular}

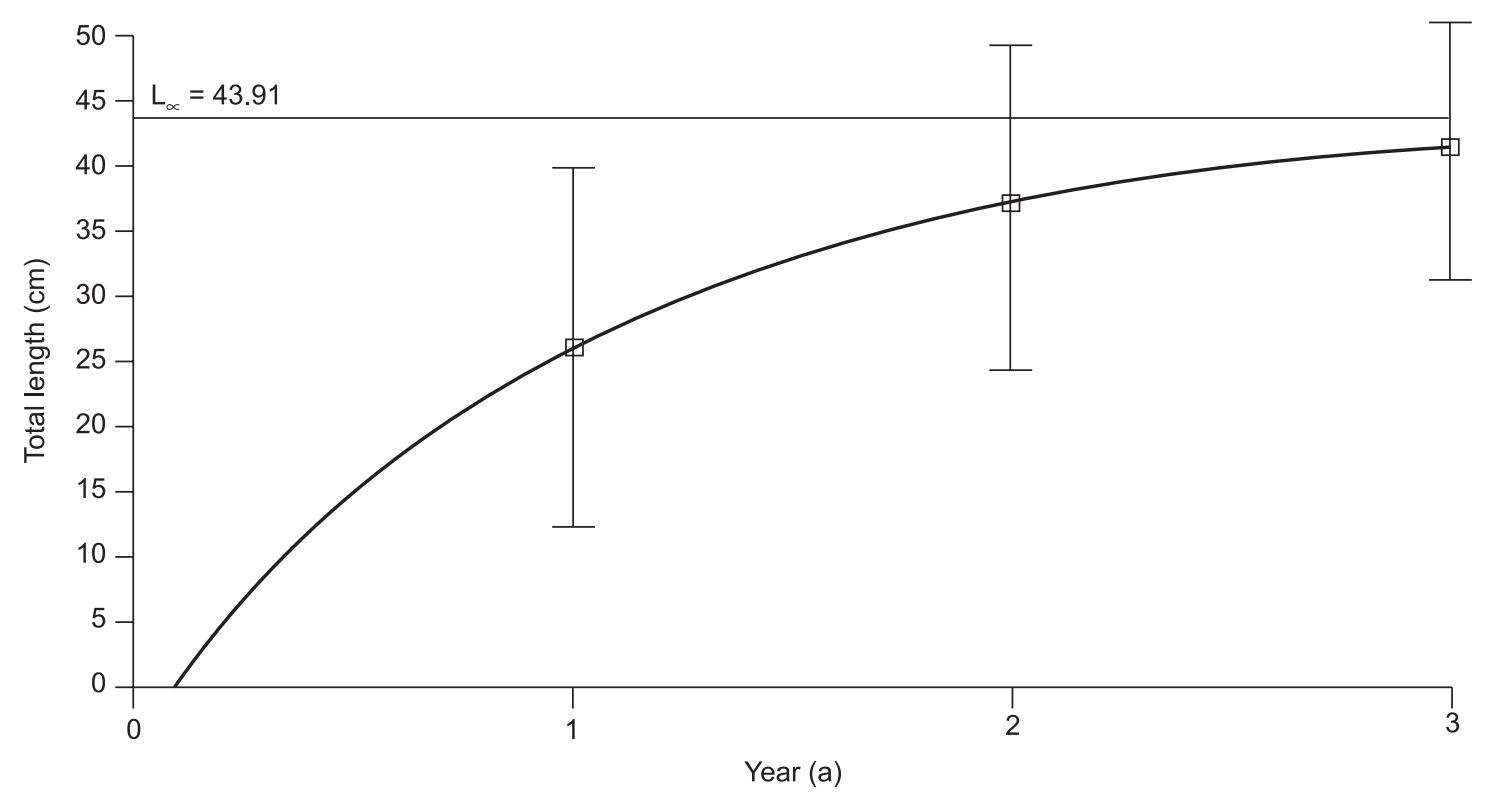

Fig. 1 - Von Bertalanffy growth curve $(n=64)$; vertical bars = standard error. 


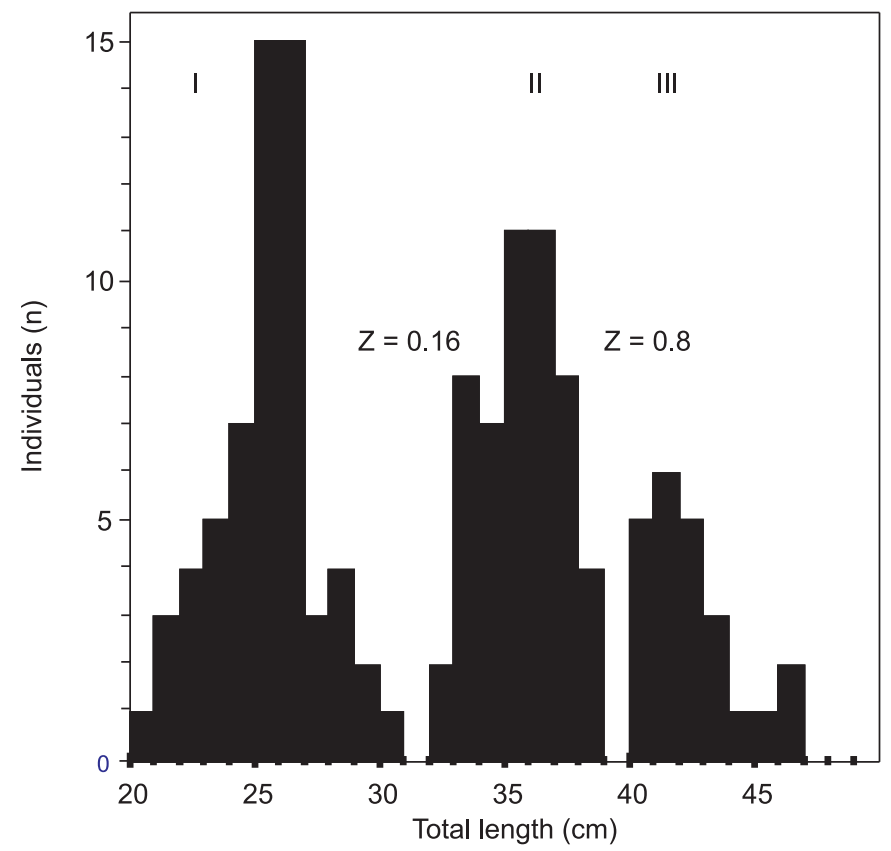

Fig. 2 - Length frequency distribution $(\mathrm{n}=134)$; I, II, and III are subsequent cohorts, $\mathrm{Z}=$ Mortality between cohorts.

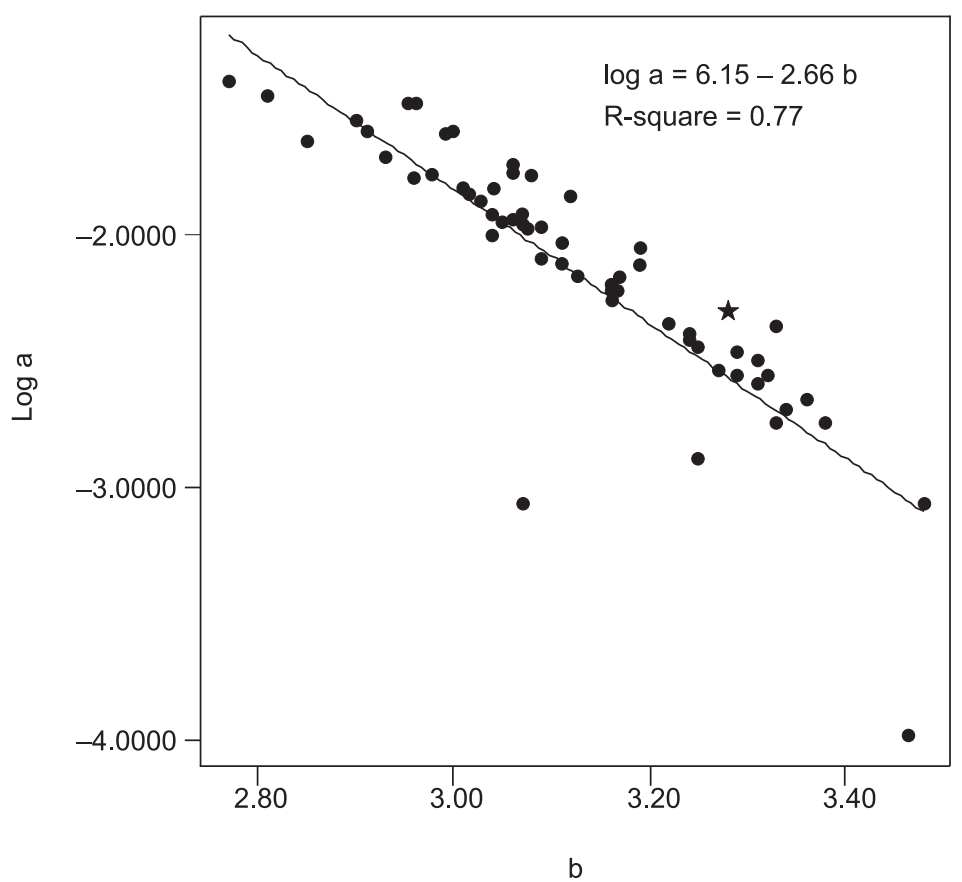

Fig. 3 - Comparison of length-weight regression parameters of the Brazilian population $(\star)$ with $60(\bullet)$ other parameters from Froese \& Pauly (2000). 


\section{DISCUSSION}

The von Bertalanffy growth curve, based on scale readings, was validated by the length frequency distribution of the same population. Both methods lead to similar results. The southern Brazilian population grows very fast, reaching a maximum age of three years and a maximum length of about $44 \mathrm{~cm}$. The maximum observed length of $46.6 \mathrm{~cm}$ at capture corresponds well to the theoretical maximum length of $43.91 \mathrm{~cm}$ based on the von Bertalanffy growth model.

Growth parameter comparisons show that the Brazilian population studied grew faster than black bass populations in the original area of distribution. (This same observation was previously made by Godoy (1954).) However, fast growth does not result in a high maximum length and weight. In Brazil, the current black bass angling record nationally is $2550 \mathrm{~g}$ (Tabela oficial dos recordes brasileiros absolutos de pesca, 2003), only $1 \mathrm{~kg}$ more than the largest fish captured in the studied reservoir, where the species was introduced about 13 years ago.

Although the Brazilian population grows faster than others, longevity is reduced to only three years. In Mozambique, this introduced species attains five years (Weyl \& Hecht, 1999), while reaching seven in both Italy and Japan (Lorenzoni et al., 2002; Yodo \& Kimura, 1996). Fourfold increased mortality between the second and the third cohorts is a strong indicator that fish older than three years die. However, the causes of this lower longevity in the studied stock are not well understood. It may be assumed that genetic diversity, particularly of the population under study but including Brazilian stocks in general, is reduced compared to that of native populations of the $\mathrm{U}$. $\mathrm{S}$. and Canada. Introductions were made with relatively few individuals more than 80 years ago. Even if additional fish were more recently imported from the U.S.A., relatively few fish gave rise to all Brazilian populations, so that inbreeding effects are highly probable. Furthermore, several studies carried out with salmonids link inbreeding with immunologic deficiencies, decreased female age at maturity, diminished number of oocytes, and mortality increase in aquaculture (Kincaid, 1976; Wang et al., 2001). The negative effects accumulate with increasing age of the individuals ( $\mathrm{Su}$ et al.,
1996). In natural populations of species threatened by extinction, low abundances of individuals and consequent reduction of genetic diversity is a constant concern. Particularly in species of high longevity and late maturity, e.g., sturgeons, inbreeding effects may contribute to population decrease of a species (Hay-Chmielewski, 1997; Wakeford, 2001).

The fact that black bass reproduces in seminatural water bodies like reservoirs, and that the species grows fast, indicates the potential of establishing self-sustaining populations in natural water bodies. Several individuals, which local anglers refer to as "green fish", have already been captured in Rio dos Sinos, to which the university reservoir is connected. In Rio Grande do Sul State's mountainous area, which is partially located in the Rio dos Sinos watershed, black bass are frequently raised in tanks and small reservoirs for a local putand-take fishery. The species has been caught in ichthyologic surveys in streams of this area (Fernando Becker, Fundação Zoo-Botânica, Rio Grande do Sul, personal communication), and some of these individuals have been included in the ichthyologic collection of the Catholic University (PUCRS) in Porto Alegre. One of them, a juvenile of $13 \mathrm{~cm}$, may have originated through natural reproduction.

In conclusion, although Brazilian black bass do not attain the size and maximum age of black bass in their original area of distribution, their fast growth and ability to reproduce under semi-natural conditions make them likely candidates for further propagation in natural water bodies. However, the possible dispersion of the species can be considered a major threat to native fish communities. Moyle et al. (1987) referred to the consequences of alien fish introduction, which are unpredictable and can have severe negative impacts, as the Frankenstein effect.

\section{REFERENCES}

ALOO, P. A. \& DADZIE, S., 1995, Diet of largemouth bass, Micropterus salmoides (LACEPÉDE), in Lake Naivasha, Kenya. Fish. Manag. Ecol., 2: 43-51.

COLARES-PEREIRA, M. J. C., COWX, I. G., RODRIGUES, J. A., ROGADO, L. \& MOREIRA DA COSTA, L., 1999, The status of Anaecypris hispanica in Portugal: problems of conserving a highly endangered Iberian fish. Biological Conservation, 88: 207-212. 
DEVRIES, D. R. \& FRIE, R. V., 1996, Determination of age and growth. In: B. R. Murphy \& D. W. Willis (eds.), Fisheries techniques, 2. ed. ASF, Bethesda, Maryland, pp. 483-512.

ELVIRA, B. \& ALMODÓVAR, A., 2001, Freshwater fish introductions in Spain: facts and figures at the beginning of the 21st century. J. Fish Biol., 59(suppl. A): 323-331.

FROESE, R. \& PAULY, D., 2000, FishBase 2000: concepts, design and data sources. ICLARM, Los Baños, Laguna, Phillipinas, 344p.

GARCÍA-BERTHOU, E. G., 2002, Ontogenetic diet shifts and interrupted piscivory in introduced largemouth bass (Micropterus salmoides). Internat. Rev. Hydrobiol., 87(4): 353-363.

GODOY, M. P., 1954, Observações sobre a adaptação do Black Bass em Pirassununga, Estado de São Paulo. Revta. Bras. Biol., 14: 32-38.

HAY-CHMIELEWSKI, E. M. \& WHELAN, G. E., 1997, Lake sturgeon rehabilitation strategy. State of Michigan, Department of Natural Resources. Fisheries Division Special Report 18, Michigan, 52p.

HICKLEY, P., NORTH, R., MUCHIRI, S. M. \& HARDER, D. M., 1994, The diet of largemouth bass, Micropterus salmoides, in Lake Naivasha, Kenya. J. Fish Biol., 44: 607-619.

ISSG, 1999, 100 of the world's worst invasive alien species the invasive species specialist group. Global Invasive Species Database. University of Auckland, New Zealand (www.issg.org/ booklet.pdf).

KINCAID, H. L., 1976, Inbreeding in rainbow trout (Salmo gairdneri). J. Fish. Res. Board Can., 33(11): 2420-2426.

LORENZONI, M., DÖRR, A. J. M., ERRA, R., GIOVINAZZO, G., MEARELLI, M. \& SELVI, S., 2002, Growth and reproduction of Largemouth bass (Micropterus salmoides, LACEPÉDE, 1802) in lake Trazimeno (Umbria, Italy). Fisheries Research, 56: 89-95.

MOYLE, P. B., LI, H. W. \& BARTON, B., 1987, The Frankenstein effect: impact of introduced fishes on native fishes of North America. In: R. H. Stroud (ed.), The role of fish culture in fisheries management. AFS, Bethesda, Maryland, pp. 415426.

MOYLE, P. B. \& CECH JR., J. J., 2000, Fishes: An introduction to ichthyology. 4. ed. Prentice \& Hall, New York, 612p.
PAGE, L. M. \& BURR, B. M., 1991, A field guide to freshwater fishes of North America north of Mexico. Houghton Mifflin Company, Boston, 432p.

PISCISTAT, 1991, Software zur fischereibiologischen Basisanalyse. Langenargen, Germany.

SCOTT, M. C. \& HELFMAN, G. S., 2001, Native invasions, homogenization, and mismeasure of integrity of fish assemblages. Fisheries, 26: 6-13.

SPSS, 1999, User's guide. Chicago, 537p.

SU, G. S., LILJEDAHL, L. E. \& GALL, G. A. E., 1996, Effects of inbreeding on growth and reproductive traits in rainbow trout (Oncorhynchus mykiss). Aquaculture, 142(3-4): 139-148.

TABELA OFFICIAL DOS RECORDES BRASILEIROS ABSOLUTOS DE PESCA, 2003, www.antares.com.br/cbpds/ html/tab1.htm.

TOMELLERI, J. R. \& EBERLE, M. E., 1990, Fishes of the Central United States. University Press of Kansas, 226p.

UNITED STATES DEPARTMENT OF THE INTERIOR, FISH AND WILDLIFE SERVICE AND U. S. DEPARTMENT OF COMMERCE, BUREAU OF CENSUS, 1996, National survey of fishing, hunting, and Wildlife associated recreation, $24 \mathrm{p}$.

WAKEFORD, A., 2001, State of Florida conservation plan for Gulf Sturgeon (Acipenser oxyrinchus desotoi). Florida Marine Institute Technical Report TR-8, St. Petersburg, Florida, 100p.

WANG, S., HERSHBERGER, W. K. \& HARD, J. J., 2001, Effects of inbreeding on genetic variation in chinook salmon Oncorhynchus tshawytscha. World Aquaculture, Book of Abstracts. Baton Rouge, Louisiana, 677p.

WEYL, O. L. F. \& HECHT, T., 1999, A successful population of largemouth bass, Micropterus salmoides, in a subtropical lake in Mozambique. Env. Biol. Fish., 54: 53-66.

YODO, T. \& KIMURA, S., 1996, Age and growth of the Largemouth Bass (Micropterus salmoides) in Lakes Shorenji and Nishinoko, Central Japan. Fisheries Science, 62(4): 524528.

ZANATELL, B. \& RASSAM, G., 2002, Stopping the invasion. Fisheries, 27(11): 21. 